\title{
Homelessness in the Suburbs: Engulfment in the Grotto of Poverty
}

ISOLDE DAISKI

School of Nursing, Faculty of Health, York University, Toronto, ON, Canada

NANCY VIVA DAVIS HALIFAX

Critical Disabilities Studies, Faculty of Health, York University, Toronto, ON, Canada

GAIL J. MITCHELL

School of Nursing, Faculty of Health, York University, Toronto, ON, Canada

ANDRE LYN

United Way of Peel Region, (formerly Social Planning Council of Peel) Peel, ON, Canada

ABSTRACT This paper describes findings of a research inquiry into the lived experience of homelessness in Peel, a suburban region located in the Greater Toronto Area in Ontario, Canada. It is based on the data from a collaborative project undertaken by members of the Faculties of Health and Education of York University with two local community organizations. The dominant theme of the narratives was that suburban homelessness is similar to being engulfed in a grotto of poverty, isolated from the rest of the community and invisible to it. Once entrapped in the grotto, it is almost impossible to escape from it. There were four sub-themes: (a) falling into the grotto, (b) living/struggling in the grotto, (c) envisioning escape routes from the grotto, and (d) beauty, community and hope in the grotto. Following a discussion of the findings, researchers describe strategies to address homelessness through promotion of social justice for all.

This paper describes findings from a research inquiry into the lived experience of homelessness in Peel, a suburban region located in the Greater Toronto Area in Ontario, Canada. It is informed by a collaborative project undertaken by members of the Faculties of Health and Education at York University, one 
member of the Social Planning Council of Peel (SPC Peel) and in consultation with the Peel Poverty Action Group (PPAG). The SPC Peel had requested the research collaboration. Their goal was to study homelessness in their region and to prepare a video for use by PPAG to inform and educate policy leaders, politicians, social and public service workers, healthcare workers, and educators, and to draw attention to suburban homelessness.

We approached the project as a research inquiry focused on the participants' perspectives of living in extreme poverty. In addition to the creation of a video, the findings which emerged from the narratives of participants are described in this paper. Readers can view the video at: http://ppag.wordpress. com/spaces-and-places-video/

\section{Background}

Historically, homelessness has been considered a problematic phenomenon of large urban centres, places that attract diverse groups of people searching for employment, housing, or other resources for life and survival. In contrast, the suburban areas of cities have been regarded as more stable communities of families with a large concentration of middle-income earners. Massey's (1996) prediction of increasing class segregation alongside growing densities of urban poor communities and intense unrest between those who have and those who have not has not unfolded as anticipated. Rather, the years from 2000 to 2010 have been marked by growth of global poverty in both suburban and urban areas (Berube \& Kneebone, 2006). "Poverty is becoming ever more widespread, and persons without sufficient resources are surfacing in suburban and rural communities where issues of homelessness mostly remain hidden and unaddressed" (Hulchanski, 2007, p.20). Preston, Murdie, D' Addario, Sibanda, et al. (2012) found that recent immigrants to Toronto increasingly settle in suburban areas, due to lack of affordable rental housing in the city core with its upscale condominium developments. These newcomers constitute the new hidden homeless living in overcrowded conditions in the suburbs.

Homelessness in this project was broadly defined as:

An extreme form of poverty characterized by inadequate housing, income and social supports. People defined as homeless include those who are absolutely homeless (i.e. temporary, intermittent or ongoing), as well as those who are at risk of homelessness (underhoused). The absolutely homeless may be living in shelters, outdoors in public or semi-public spaces, with friends or relatives (couch surfing). Those who are "at risk" of homelessness may be precariously housed, living in hotels, rooming houses or apartments, and transitional housing, but who may potentially lose their housing due to eviction, inadequate income or because they are fleeing violence. (Gaetz, 2008)

Homelessness and poverty in urban areas are well researched, particularly their impacts on health, (Bryant, 2004; Cheung \& Hwang, 2004; Frankish, Hwang, \& Quantz, 2005; Hwang, 2001; Layton, 2000; Levy \& O’Connell, 
2004; O'Connell, 2004; The Street Health Report, 2007; Woolf, 2007). We know that morbidity and mortality rates are significantly increased for those lacking stable housing and other associated social determinants of health, such as secure access to food and healthcare (Hwang, 2001; Hwang, Martin, Tolomiczenko, \& Hulchanski, 2003; Mikkonen \& Raphael, 2010; O'Connell, 2004; Raphael, 2003). Some literature also describes the lived experiences from the perspectives of those who are homeless (Acosto \& Toro, 2000; Daiski, 2008; 2007; Lafuente, 2003; Davis Halifax, 2010, Davis Halifax, Meeks, Yurichuk, \& Khandor, 2008; Davis Halifax \& Yurichuk, 2007). And, further, we know that local and regional politics and race/gender issues impact how homelessness is experienced, emphasizing the need to bring multiple stories of homelessness and poverty to light (Berube \& Kneebone, 2006). Allard (2009) reported that social services in American cities are seldom located in the downtown areas, where the poorest citizens live, and therefore effectively out of their reach. He called for service agencies locating closer to those who use them. This contrasts with Canadian cities where major charitable, social, and healthcare services are mostly located in densely populated downtown cores where upscale condos now prevail. Both Allard (2009) in the US, and Hulchanski (2007) in Canada also observed a recent shift of poverty and homelessness into the suburbs where social services are ill-equipped to keep up with the increasing demands.

For the suburban area of Peel Region with a current population of $1,159,400$ the last available statistical data clearly show a disturbing trend of growing poverty and homelessness: In 2010 shelters in Peel served 11,920 individuals, including 1,974 families, 696 youth and 3,134 dependents (Region of Peel, 2011). Between 2001 and 2006, the rate of low income families with children under 17 years of age grew by 4.7 percentage points, almost 5 times that of the rest of Ontario combined. In 2006, 20\% of children under 6 years of age were living in low income families, up from 14 per cent in 2001 (Region of Peel, 2011). Between 2005 and 2006 the use of services to prevent evictions rose by 14\%. Finally, in 2007 over 14,000 families were on the waiting list for affordable public housing, for which the average waiting period for an individual or family was more than 17 years (SPC Peel, 2009). With the recent recession it can be assumed that the needs would have increased further. In March 2010 alone more than 14,500 separate individuals used local food banks (Region of Peel, 2011).

In spite of the above statistics, the growing numbers of homeless persons in Peel remain largely unnoticed. Not surprisingly, anecdotal reports from PPAG members suggested that because the general public is not aware of or prefers to ignore homelessness in their suburban community, politicians who tend to respond to the public's interests and visible problems also pay little attention. As the invisibility itself seems to be a major contributor to the hardships of suburban homelessness, we believe that exposure and public education are required urgently. 


\section{Method}

Before starting, the ethics review of the larger project had been carried out by the university's Office of Research Administration. The data for this paper were taken from the transcripts of the audio and video recordings interviews of the larger project. This paper is focused on the lived experiences of persons who were previously or who currently are homeless in Peel Region and who are considered experts of their own lives. Our goal was to obtain an in depth record of the experiences of homelessness in this community. A Gadamerian hermeneutic approach best fit our collective intentions and research purposes; specifically, this means that understanding emerges out of a circular relationship of the engagement between what is known and unknown while always influenced by context, history, values and meanings (Gadamer, 1990). This approach focuses on the wholeness of lived experience and the co-constituted nature of knowledge and understanding, the in-between of familiarity and unfamiliarity. Emergent understanding thus involves a movement to new meaning. Since all four researchers had previously conducted research with homeless people in urban areas, we were able to draw on the familiar by connecting to the unfamiliar of homelessness in a suburban context to discern the uniquenesses of these latter experiences.

\section{Recruitment and Interviews}

In community-based research, collaboration with community members and groups is essential (Minkler \& Wallerstein, 2008). With the mediation of local charitable agencies we spent the early months of this project walking the streets, ravines, and wooded areas with men and women who knew homelessness from first-hand experience. We discovered a community that lives in the margins of the larger community: in alleys, doorways, staircases, abandoned vehicles, and clothing boxes, mostly hidden from public view.

We posted flyers with an invitation to participate in the project in local soup kitchens and shelters. Fifteen participants were eventually recruited for this study, which we designed purposively to include as many diverse individuals as possible. As in-depth interviews generate large amounts of data, the intent was to focus on depth and quality rather than breadth, with the aim to increase understanding rather than providing facts (Munhall, 2012). The primary research question was: What is the lived experience of homelessness in suburbia? To better understand homelessness in this context and in keeping with research guided by hermeneutic phenomenology, our role was to listen, discern, and illuminate the meanings persons gave to their experiences of homelessness. At the end of the interviews, which were either recorded on video or audio-taped and lasted between 40 and 90 minutes, each participant received an honorarium of $\$ 15$ Canadian.

The members of the research team created the interview guide and conducted the interviews with the participants. Questions began with an 
open-ended invitation to speak about the experience of being homeless. Further questions were: From the participants' perspectives, what led them to becoming homeless? What are their day-to-day lives like? What strategies are required in order to prevent homelessness or, once homeless, to get out of it? What is helpful, what hinders? Prompts, such as tell me more about this or please go on, were used whenever we felt they were necessary to obtain as much depth as possible in participant description.

\section{Data Analysis}

The interviews were transcribed verbatim, and we employed Diekelmann, Allen and Tanner's (1989) seven-stage collaborative process of analysis. We, the researchers met regularly to review transcripts and discuss the meanings embedded in the individual texts. Each of us created stories from several transcripts depicting the experience of homelessness from each person's perspective. We then shared and explored identified meanings and repeating ideas emerging from the analysis. Once we agreed on the core ideas, we discussed and refined their meanings within the context of the emerging overarching theme called a constitutive pattern (Diekelmann et al., 1989). As homelessness in the suburban context is mostly invisible and unacknowledged, it seemed to entrap the persons who fell into it and, once there, it seemed nearly impossible to escape from it. The over-arching experience of homelessness emerging from our research was that it was like being engulfed in a grotto. We then finalized the sub-themes and their emergent relationships with the over-arching constitutive pattern. The four related sub-themes found in the narratives were: 1) falling into the grotto; 2) living struggling in the grotto; 3) envisioning escape routes from the grotto; 4) beauty, community and hope in the grotto.

Historically and structurally grottoes have been associated with underground locations. The many connotations of grotto include: earthiness, fertility, darkness, and death (Connelly, 2003). Therefore, the idea of the grotto inspires scary imagery of dangerous underground chambers.

The nuances of engulfment connoted by the grotto include being swallowed, lost, "to disappear underground" or "to plunge deeply and inextricably into a surrounding medium" (Oxford English Dictionary, on-line version). This sense of being "disappeared underground," relates to the effects of poverty and homelessness; of feeling invisible and unable to escape. It refers to the lack of a presence on the landscape, in contrast to downtown areas where people sitting and sleeping on the street visible to all are a common sight. However, it needs to be mentioned that, even in cities, those who are visibly homeless are only a small percentage of the overall numbers. In 2009, for example, the City of Toronto reported the number of those visibly homeless in the downtown area only, those easily counted in the shelter systems and by street outreach, as 4,390 (The Wellesley Institute, 2009, p. 4). This number represented a snapshot as the hidden homeless, estimated at up to $69 \%$ of 
total numbers, are staying out of sight for various reasons, including survival strategies. Thereby they are left out of the count, under-representing the phenomenon.

Finally, there is also another side to grottoes: they can be located amidst beautiful gardens and landscapes (Miller, 1982). As engulfment depends on the media in which one is engrossed it also can mean being immersed in friendship and love or communities, therefore offering hope and possibilities, which is reflected in the last sub-theme. The various meanings were present within the data collected.

\section{Findings}

We begin by reporting on the participants and their perspectives on suburban homelessness. Pathways into poverty are then discussed. Daily life and institutional barriers to escaping poverty are described. Finally, what participants believe would help them effectively and permanently leave homelessness is presented. Emerging patterns of community and cohesion are then identified, followed by discussion, our conclusion, and our recommendations.

\section{Demographics}

The participants represented a diverse group of people living in the alleys, door ways, staircases, abandoned vehicles, clothing boxes, shelters, and substandard rooming houses of the suburban terrain. There were seven women and eight men. Ages ranged from early 20 s to 70 s and included ethnic groups of Caucasians, African Canadians, First Nations peoples, persons of South Asian origins and some of mixed heritage. Most were Canadian born, with about one third having immigrated. Some were former professionals, others former trades persons, while others had little work experience. Several persons were employed in casual labour as well as social services. Almost all volunteered currently or previously in the local drop-in centres or food bank. One participant ran for local councillor at the time. Three pensioners were included. Some participants were single, some had children, and most were divorced or widowed. Few had any family support. They identified as heterosexual or queer. Almost all were in poor health and suffered from a variety of acute and chronic health conditions. Two engaged with the arts, one a visual artist and another was writing poetry. The common bond they all shared was extreme and lasting poverty. In order to protect the participants' identities pseudonyms, not real names, will be used with the quotations below to illustrate the themes. 


\section{Engulfed in the grotto}

The concept of engulfment in the grotto emerged as the central metaphor representing what it is like to live in poverty without sufficient housing or resources and became the overarching, constitutive theme of the stories we heard and recorded. All participants described an overwhelming sense of being swallowed, trapped and invisible as in the following quote:

We're going round and round and round ... So, we don't pull out of the situation we're in. We stay in that same hole. We can't crawl out of it because...we can't get the help. Somebody to pull us out of that hole ... (Art, living in a rooming house, formerly on the street for many years)

Further we learned how life in a grotto is physically hidden from most eyes, pinpointed by the following quote:

People say there is no homeless in Peel. When you walk down the street here you don't see people sleeping on a bench in the daytime or sitting on the streets [like] you do if you were in Toronto. [Here homelessness] is tucked away. (Beth, an older woman previously couch-surfing with friends when on widower's pension alone; now receiving old age security she affords a room in a rooming house)

In time one's sense of dignity gets eroded and what can become a homeless identity is shaped and further contributes to the sense of entrapment with no possibility for escape. One participant shared this sentiment with us:

When you are chronically homeless there is a certain sense of resignation and accepting this as your lot in life .... It means ... existing in terms of where is my next meal? Where is my next bed? This is who I am . . . (long silence). So, when you resign yourself to that, you give up and you exist . . 25 years in the capacity of a homeless man full time, chronic health issues .... (Norm, a middle aged man, previously homeless in many different places after being sexually abused as teenager; now lives in a rooming house; volunteers for community outreach and receives welfare)

Life in the Grotto with its sense of desperation seems to change the self perceptions of those who are homeless as being/becoming the "other." They also described diverse ways of falling into the grotto - the first sub-theme.

\section{Falling into the Grotto}

Like, you don't plan to be homeless . . you'll be paying your mortgage and things collapse. You come home from work one evening; your door is locked with the sheriff there, you wonder, what happened? (Diane, mother of five, unemployed, living with her children in her mother's apartment)

And,

I am not homeless but one of my greatest fears is becoming homeless. I live 
on CPP (Canada Pension Plan) and old age security, which equals about $\$ 720$ a month. I don't have any money for transportation and I do not get a bus pass. My rent is $\$ 600$ a month. I have had my name in for subsidized housing for years but there is a long waiting list. I only have $\$ 120$ for the month to cover food, medications, clothing, toiletries, etc. I use food banks once a week to get through each month. (Ethel, a pensioner, lives in small apartment)

The following story of Sam, a man who immigrated to Canada is also quite typical. After he arrived in Canada, he started working in a small grocery store for minimum wage while supporting a wife and four children:

I was never out on the street but I live in constant fear of homelessness, which means "sleeping under a tree or on an air duct." When I first immigrated to Canada 20 years ago, we bought a beautiful, big house we could not pay for on my modest salary. After we exhausted all savings we had to declare bankruptcy. You buy a home out of emotions rather than practicality ... Immigrants fall into this trap.

The family was evicted, and they continued to experience inadequate and insecure housing. For five years they lived without gas heating and hot water; as they were unable to pay for both, they chose to pay the electricity only, which meant they had to use the oven for heat in the winter. "To take a bath we had to heat the water and carry it upstairs or bathe in icy cold water . . My wife eventually left me and the children. Poverty put a strain on our family" (Sam).

Betrayal and theft can also lead to homelessness. William, a former professional now a pensioner, was defrauded by a "friend" he trusted. $\mathrm{He}$ now lives in a shelter and currently uses a wheelchair:

I have become homeless since retiring. I met someone that needed some help so I helped them out, lent them some money and somewhere along the line they got hold of my interac (bank account access) card and cleaned out my bank account so that I was completely broke. I . . didn't have any money to go anywhere . . .. I've slept in tents. I've slept up in trees. I spent a couple of nights under the bushes over at the church. The overhang there was dry and you didn't get wet. I put my knapsack down, I put my head on it and went to sleep. (William)

Fleeing domestic violence is another door-way into the grotto of homelessness and poverty. Beth, cited above, described her experience of isolation and entrapment in poverty while in her abusive marriage, which also affected her children:

I lived in an abusive relationship for 28 years. I had four children and we were very poor ... never had enough money for food. My husband would never give me any money and he took the child benefit cheques from me as well. I lost two children while pregnant probably because I was starving. I lived in fear and so did my children and I have a lot of guilt about that. I felt very alone and I felt like there was no one I could trust. We all have scars from that experience. 
Besides spousal abuse, child abuse is also a frequent pathway to homelessness. Several participants reported physical or sexual abuse in their own families, while others described unhappy experiences in a string of foster homes. Most of the time, these events led them to run away as soon as they could, only to encounter more abuse and violence on the streets.

Several participants related losing their jobs and then their homes. Even though some participants were casually employed and worked for minimum wage, they noted how hard it was to save for the required first and last months' rent and to keep up the payments; this economic precariousness entraps them in poverty. People in extreme poverty therefore live at the brink, at best, in constant fear of losing their housing, or at worst, they actually lose their housing and cycle in and out of living with relatives/friends, in rooming houses, on the streets and in shelters. The grotto might have different recesses in which one may live and often move about, but no exit. Living in the grotto means struggling in the grotto - the second sub-theme of the engulfment pattern.

\section{Living struggling in the grotto}

The following quotes typify the subtheme of living/struggling in the grotto:

I was sleeping in the bus terminal, and the alleyway . . . in a van seat, but it blocks the wind so it's just like, dark and dingy...just scary. I had garbage thrown at me. I had beer bottles thrown at me, well...this is my home so please don't disturb me ... It's dark and lonely and it's full of bugs (Karen, 21 years old, lives with addiction and frequent abuse on the street; she had just found a room in a rooming house).

And, "to be homeless means to be unnumbered and unidentified. It also means an unaccounted citizen living outside your constitutional rights; a NOBODY" (Alex, middle-aged, living with bi-polar disorder, cycling between street and shelters).

Entrapped in poverty, there are ever-present dangers when struggling in the grotto. Like the woman above almost every person talked about experiencing violence on the street or in shelters, ranging from having belongings stolen to being assaulted, physically and/or sexually. One man related his experiences of sexual exploitation as a homeless youth, which was similarly represented in the narratives of several other participants, both women and men:

Here I was, 16 years old and naïve . . There was this guy who told me how much God loved me and how God had brought me to him so he could teach me what love was all about. Having won my confidence and my trust, he went on to sexually abuse me over a three month period. I spent the next 25 years running away from that shame and guilt. I became dysfunctional . . . huge amounts of depression, post-traumatic stress disorder, and suicidal ideation. (Jean, describes himself as chronically homeless and drifting for many years, now has small apartment) 
Karen, cited above, described how she once was violently attacked:

The knife went in and then through and then out. And he stabbed me ... and I had both my arms pinned together ... For 24 hours I couldn't literally move my arm because the knife was right through it.

Despite these dangers, some participants who were absolutely homeless preferred to stay on the street rather than in shelters. "Shelters here are packed. A couple of years ago a lot of people lost their jobs, they lost their houses. A lot of houses went under. And where do they [people] have to end up? In shelters" (Diane, previously cited).

Shelters are avoided due to overcrowding, insect infestations, and perils associated with sleeping in close quarters, including health and safety concerns: "So, you've got a dorm full of 20 guys, you don't know who is doing crack, who is doing speed, who is doing heroin, you don't know who is an alcoholic" (Art, previously cited).

Violence, however, is often also perpetrated by those who are supposed "to serve and protect." Norm, cited previously, who lived on the street for years, described his experience with law and order agents: "Can't sit too long or they [police] chase you off. Better to keep walking. Also, if they see you hanging around the park or sleeping on a bench and if there has been a break and enter in the area they assume it was you." The following is a vivid portrayal of encounters with police similar to several others' experiences:

I avoid the police like a plague. Well, my experiences with the police have been pretty rough, pretty bad. I've been on the underside of society since I was a teenager ... police when they deal with stuff on a regular basis they become very cold. There are good police officers but there are ones that just.., I've been handcuffed for sleeping on [someone's] property so hard that my wrists swelled up . . . they bend the wrists and put you to the ground and say all sorts of nasty stuff in your ear, (Graham who was episodically on the street, now lives in rooming house, works casually and receives welfare)

Finally, more subtle forms of violence, such as lack of respect, dehumanize as this woman explains:

Most people think you are just a bum, you are a street person. They [we] are actually "real people." Maybe [our] money is not enough. People should know I am "me," I have certain morals I'd like to live by and to keep. (Diane, cited previously).

The ultimate existential violence is denial of personhood, being called a nobody. Art, cited earlier, related that when a young child looking at him asked his mother, “'Who is that man?' The mother answered: 'Nobody dear, he's homeless."' (Art).

When people with low incomes can afford housing on the private market, the only available option is substandard houses in the suburbs. Some of the rooming houses were described as "crack houses." All were overcrowded, with small rooms, frequently without windows and lacking proper cooking 
and food storage facilities. The shortage of affordable housing, and a lack of oversight, means landlords can exploit the situation with impunity, as Norm, who was previously cited, explained:

I call these guys scumlords, not slumlords, scumlords because they take advantage of the poor and use it to their advantage to get monetarily ahead, which is all right but when you do it to the detriment of somebody else's wellbeing it's wrong.

Alex, cited previously, spoke of "mice all over the kitchen" in his rooming house. Graham, also previously cited, described his housing and living conditions in a typical fashion:

I live in a rooming house. I pay $\$ 400$ per month for a room and shared kitchen with 11 other adults. Two out of the four burners work on the stove. The fridge door falls off. Some people do not have windows in their rooms. After my rent I have $\$ 120$ to live on for the month. I go to the soup kitchens and the food bank every week.

Beth, previously cited, talked about how living in her apartment is extremely difficult due to her poor health:

I live in a very small, very crowded apartment. There is no bathtub. The laundry is downstairs and I can't always get there. I find it too difficult physically to get back up to my apartment. I have a bad back: herniated disc and scoliosis as well as a small hip fracture. I also need medication for my kidneys. My knees are bad and I have a bad infection in one of my toes. There are days I just can't get out of bed because I am not feeling well enough.

Day to day challenges were often met with ingenuity and defiance, Allen, has a physical disability due to work related injury He previously lived on the street. He now receives a "small pension," works casually, and lives in rooming house. He discussed some innovative strategies:

Staying clean is the hardest thing! Even though I have a bus pass nobody wants you in the washrooms at the bus station. I sometimes see people putting paper towels on the floor and giving themselves a sponge bath. To keep clean I use baby wipes. I can clean my whole body with one wipe.

He went on to describe his strategy for sleeping on the bus during the long suburban routes:

When I was on the street, welfare cut me off. I had nothing. On the buses during the day I would sleep all the way out on a route, get off and then walk around for an hour and get on another bus and sleep all the way back. I can get a good hour of sleep on a bus. The bus shuts down around one or two in the morning. From then until five or six I walk to keep warm. It is pretty hard to stay warm at nights until March, April. I carry newspapers to keep me warm when sitting on a park bench. (Allen) 
Karen, cited earlier, talked about the recent closing of the only women's shelter in the area, forcing her and other women who cannot afford the fare to the closest women's shelter, a long bus ride away, to sleep on the street. She also related that the food bank/soup kitchen was recently moved to the outskirts of the city, which she believes to be a deliberate strategy to make life difficult, inciting defiance:

Trying to get us, all bums and alcoholics and crack-heads, they're just trying to get rid of us so we can move to different places. But, as we all said, we're not leaving. You can't make us leave. This is where we were born and raised. This is where we were growing up, we're not leaving. I'll put up a fight to stay in my area. (Karen)

Coexisting with this persistent sense of space and right to stay were imaginings of escape routes from the grotto.

\section{Envisioned escape routes from the grotto}

Participants made several recommendations that they thought would be helpful to escape the grotto. Consider the following quotation by Jean, a long-time street survivor cited previously, referring to social agency workers. "[Workers need] to have the capacity to build empathy. Not sympathy, empathy. You have to create an alliance with the people that you're dealing with..." (Jean). The social support agencies such as Ontario Works were frequently described as insufficient, while the workers' large workloads and job stress were acknowledged. The following statement captures this sentiment:

Most of the Ontario Works [employees] ... They should be...a little bit more compassionate ... And then you wonder why their turnover of staff is . . constant ... Because ... each worker, roughly, has 160 to 300 people per month ... some of these workers cannot take the stress and leave the job. And they transfer you almost every 3 to 6 months to a new worker. So, you get used to that worker ... They want to help you and you're getting ahead and what happens? They introduce you to somebody else that has no compassion at all. And then you start from scratch. (Graham)

Alex, who lives with bipolar disorder, also shed light on how hard it is to negotiate social support. He is currently on welfare, trying to get disability pension:

I put in over 40 years of work, off and on. I have a good trade but I'm getting to a point ... the doctor says my working days are over. Nobody is listening ... I've been actually declared . . . unfit to work, mentally-wise . . . all these problems are starting to build up...I have to let it out, I have to speak to somebody who is going to listen ... (Alex). 
A lack of addiction treatment centres represents a barrier for those wanting to quit their addictions. Treatments provided often are thought to be too short in duration and therefore ineffective. They are usually not available at the time the person is ready:

Putting somebody in a detox for a week and then kicking them out on the street does not work because two days later they'll be back on booze and/or drugs or whatever the problem was. They'll promise somebody when they think they're ready, they're going to go for treatment and you can't get them in a treatment centre because there are not enough spaces available. (Tina, a middle aged woman, now housed, volunteers for outreach work and receives welfare)

Jean, who is divorced, lives in small apartment where his young son visits on weekends. He explained:

Anything that will improve the environment ... to [help with] addiction. Like I said, you don't become an addict for nothing, you don't say one day, “you know what? I'm going to become an addict today" ... There are reasons why and those reasons have to do with your early childhood, the way you've been treated...I've been an addict since I was 11 ... you're raped and you're molested and you do fourteen foster homes between the age of three and 11. (Jean)

Most participants stated they did not want to receive government handouts. Finding stable employment was seen as most important and more job counselling and regulations to prevent exploitation through casual insecure employment were recommended:

Need to be in a stable job to provide for my family and a roof over my head. That's help. Because that's the main thing of life right now. And...at the moment it seems like there is no door opening ... I have the key but no door ... (Diane, cited previously, had taken courses for community work)

Oversight of "slum landlords" was a strong recommendation by participants to prevent the exploitation in rooming houses. Building affordable public housing was named a priority with several participants making recommendations to convert vacant buildings into housing. The fourth subtheme is a reminder that human beings have ways of seeing and believing in beauty, community and hope, despite struggle and despair.

\section{Beauty, community and hope in the grotto}

There were many tales of friends helping friends--providing a place to sleep till they get back on their feet, or lending money, and of dedicated workers that make a difference. Several participants looked for ways to create a community as this person explains: "My biggest fear [is] loneliness. You know what I mean...not being accepted...so I'm trying to get involved in the community itself" (Alex, cited earlier). "Helping others helps, that is why many of us volunteer to 'give back'," Diane, cited earlier, explained. She 
continued, "I now volunteer at [a drop-in centre]. I want to work, not stay on social service ... helping other people straightening out their lives, it helps me to cope with mine, deal with my own stress."

Several participants talked about ingenuous strategies to be and share with family and friends. Graham saved every penny to be able to take his daughter to a movie every Saturday. Jean took his son to the airport to ride the escalators for fun and enjoyment together on his birthday, because that is all he could afford. Many helped each other out, letting friends stay with them in their rooming houses. Hope was described by many as what kept them going. William, who lives in a shelter, despite having been defrauded by those he helped stated: "I still have hope that, one day, I will get an apartment and a black cat - this hope is what keeps me going" (William). And Lorna (who also volunteers in the community and lives in rooming house, expressed: "I've always had hope. I spend a lot of time hoping and praying that everything is going to work out" (Lorna). Hope is also expressed by Karen who writes poetry in the evening and by Alex in painting landscapes.

Lastly Karen stated: "I am all by myself. Since 13, living on the streets. I have been suicidal, I've been in mental wards; I have been raped five times, but I'm still here and I hope to become a nurse one day." Engulfed in the grotto of poverty was the overarching theme or pattern researchers identified in the descriptions from the participants. We now turn to the literature to discuss the theme and subthemes with some additional detail

\section{Discussion}

\section{Comparing urban and suburban homelessness}

We found many commonalities with urban homelessness in our suburban project. People seem to become homeless following several pathways into poverty: Loss of job, disabilities, addictions, loss of housing due to inability to afford the rent, divorce and domestic abuse of women and / or children are amongst the main reasons (Clapham, 2003; Daiski, 2008; 2005; Klodawsky, 2010; Wellesley Institute, 2009). Once they fell into poverty, our participants described the difficulties they experienced, such as when applying for social assistance. The Canadian Welfare system is inherently punitive through measures such as low welfare rates, which steadily declined over the past two decades, and which have restrictive eligibility criteria (National Council of Welfare, 2010, [recently axed by the federal government]; Organisation for Economic Co-operation and Development, 1999). Moreover, in hard times social services are typically the first to be cut (Craig, 2010), which forces people to choose between essentials, such as paying rent, having electricity, or buying food (Allard, 2009; Scanlon \& Adlam, 2008). When accessing social service agencies, like their urban counterparts, participants talked about how hard it is to qualify and how easily social benefits are lost altogether due to minor irregularities (Daiski, 2007, 2008; Street Health, 2007). Just like in 
urban areas (Daiski, 2007) addiction treatment facilities, long underfunded, were reported not being available for people ready to quit.

Congruent with Allard's (2009) and Hulchanski's (2007) observations we discovered that as poverty moves progressively to the suburbs the already scarce resources there are increasingly unable to keep up, overburdening those who work there. Social agencies in the suburbs are greater distances apart than downtown and hard to access without transportation. The few existing shelters were described as packed, unsafe and unable to meet the needs. That shelters are unsafe and have strict and oppressive rules, such as early curfews and lack of privacy, has been widely reported (Acosta \& Toro, 2000; Daiski, 2008; 2007; Lee \& Schreck, 2005; Miller \& Keyes, 2001). To make things worse, in the suburb of Brampton discussed here, the nearest shelter for women is a long bus ride away in the Mississauga area. As no drop-ins or soup kitchens exist at the shelter location, the women have to come back to Brampton each day for food and social services. Those unable to afford transportation are forced to sleep on the street, risking assault and rape, as described by Karen in our project.

While social housing is scarce in downtown Toronto, in the suburbs it barely exists at all, as the long wait times for admittance to shelters proves, such as an average of 17 years in Peel Region (SPC Peel, 2009). When people finally found housing in the private sector, it was usually substandard and environmentally unsafe, as well as exploitative. While lack of safety in housing had been reported in downtown Toronto too (Daiski, 2007, 2008), in suburban areas due to the scarcity of social housing there, the problem seemed even worse. Jacobs (2011) described how substandard housing conditions lead to social inequity and disproportionately ill health. We found this to be true with our participants who almost all reported major health problems.

In Peel Region soup kitchens and drop-ins exist in but a few places. One of the soup kitchens combined with the only food bank, located at the outskirts of Brampton is difficult to reach, as it is several kilometres from the city centre. We also heard about the adversities participants faced performing daily rituals of personal hygiene where apart from two faith-based drop-ins, no shower facilities exist.

With fewer public places in the suburbs, where those who are homeless can gather, trespassing on private property leads to more violence by authorities. As Lee and Schreck (2005), Gaetz, O'Grady and Buccieri (2010) and Gaetz (2004) have described, behaviours which are necessary for survival, socalled nuisance behaviours are criminalized. Laws against loitering in public places give the police the power to remove and arrest people, making them targets of institutional violence, as the participants described. As there is no alternative place for them to go they are forced to hide in unsafe locations to escape the authorities, putting them at increased risk for violence from criminals. Valuable police time handing out tickets which can never be paid and incarcerations of the poor are other consequences of living on the street (Gaetz, et al. 2010).

Overall, suburban and urban homelessness seem mostly alike, but the 
degree of hardship appears even more intense outside of the city core, as suburbs lack resources and adequate, affordable public transportation; after all, suburban areas were never designed around the needs of the poor. The most important difference between the urban and suburban homelessness experiences is that the latter is much more effectively hidden. Social stigma and safety concerns encourage the homeless to stay invisible by hiding in ravines and woods and blending in with their surroundings as much as possible. This makes it easy for passers-by to overlook whatever signs of homelessness are around them. The suburban homeless person effectively disappears underground in the grotto of poverty.

\section{Homeless identity and social justice}

Our participants, feeling excluded from the rest of the community, deplored the lack of respect they felt should be shown to them as humans "who live by their own values." Noddings (2002) writes about society viewing housing as an "extension of oneself" (p. 445). Lacking housing therefore challenges a person's identity. How interpersonal isolation and self-alienation of people who are homeless is fuelled by the stigma society attaches to homelessness was described by Rokach (2005). Her participants, like ours, felt shunned by society and they too considered themselves "unidentified and un-numbered." Lafuente (2003) discussed how these attitudes led to feelings of powerlessness amongst her participants who internalized the meanings of "bum" and "street person," the same terms used by our participants to describe how they believe to be seen by others.

Referring to a homeless person as a "nobody," as some of our participants had related, is an example of ultimate denial, as "nobody" then is homeless; it also represents an extreme form of dehumanization. If the existence of homeless persons by members of society is acknowledged at all they are, at best, becoming the "other" (Boydell, Goering, \& Morrell-Bellai, 2000; Johnson, Bottorff \& Browne, 2004). Kearney (1986) discusses "othering" as scape-goating of individuals thought undeserving and responsible for society's ills. This moral component of othering acts as a strong barrier to the public's will to prevent and abolish homelessness and is also present in the neo-liberal discourse of individuals' responsibility for their own situations. Accepting a common humanity in all and recognizing our individual situations as inherently unequal is an imperative of social justice. Craig (2010) believes that looking beyond the neo-liberal discourse of "equal opportunities for free independent individuals" towards achieving outcomes of equity for all, a redistributive type of justice must be developed. Klodawsky (2010) advocating for "rights to the city" for all, claims that cities (and other places) should be "inhabitated" by all citizens rather than becoming the "private properties" of a few. While the context might change, homelessness and poverty emerge from social inequities and are inherently unjust in any environment. 


\section{Recommendations for change}

We believe that being homeless is a denial of social justice. Padgett (2007) found that Housing First approaches work even for those living with addictions and mental illness: Those who were housed experienced themselves as ontologically secure; having a place of their own allowed for daily routines, privacy and provided a secure base. Coldwell and Bender (2007) too showed that, even for those who experience severe mental illness, proper support systems helped to reduce clients' symptoms and kept them housed. Feeling secure was deemed the determining factor. Similarly, a new city-run program Streets to Homes is currently operating in Toronto and preliminary evidence suggests it is effective (Falvo, 2008). This program subsidizes private housing for people on the street and initially provides support and counselling to make the transition to a housed life easier. However, no such capacity for support exists in the suburbs so far. As this program targets the visibly homeless on the street, which neo-liberal governments might see as embarrassing and as interfering with business agendas, there is less money left for upgrading and maintaining existing public housing, which precipitates a trend towards privatization (Klodawsky, 2010). The danger is that without oversight market based housing can lead to exploitation and neglect, as we have seen. In addition, as long as suburban homelessness remains invisible it will not be on the political agenda. Therefore awareness-raising is the first important step.

Feeling excluded, many of our participants were trying to create ties in the community by volunteering their services to help others. Hilfinger Messias, DeJong, \& McLoughlin, (2005) reported that homeless women who volunteered were seeing themselves as empowered, possessed deeper insights and understanding and were better able to empathize and win the trust of those currently homeless. However, there is a caution attached to volunteering: work provided by people in extreme poverty for free, can easily lead to further exploitation. They should be reimbursed justly.

To abolish homelessness in any environment, we agree with Zlotnick, Robertson and Lahiff (1999) that a stable, adequate income is a prerequisite to stable housing and food security. It is also the most effective strategy to attain equity as individuals then can choose how to spend their money according to their needs (Kirkpatrick \& Tarasuk, 2009; Woolf, 2007). Current social assistance programs, including pensions, as well as minimum wage, should be raised to a level where recipients can pay for basic necessities (Daily Bread Foodbank, 2012). Safe and secure housing, in turn, is a crucial prerequisite to health (Krieger, 2007; Raphael, 2007) and could go a long way in improving health and healthcare costs (Frankish et al., 2005; Padgett, 2007). It might decrease incarcerations (Gaetz, 2004), reduce violence and assaults (Gaetz, et al., 2010) and generally improve health and quality of life (Orpana, Lemyre \& Gravel, 2009).

Further prevention of homelessness through timely interventions such as counselling for family violence, job retraining and emergency funds should be priorities. As our participants suggested, more public housing and oversight of 
private rooming houses are needed, and addiction treatment facilities should be readily available. Police and security personnel need education about serving and protecting all citizens, including those who are homeless and efforts should be directed to create public spaces where people can stay safely without fear of being attacked and raped rather than criminalizing those who have no place to go. Public washrooms and shower facilities would also make life easier, such as already exist in downtown Toronto. It seems that societal attitudes and ignorance, silos of complicated bureaucracies and neo-liberal ideologies are barriers "to crawling out of the hole" and must be overcome.

\section{Limitations of the study}

This study took place in the suburban Region of Peel of the Greater Toronto Area and with a relatively small number of participants. It was not meant to be exhaustive but to begin to shed light on homelessness in the suburbs, which is mostly hidden. While the findings might be specific to this particular place, the dearth of resources and social institutions outside of city cores, as well as the relative invisibility, we believe are quite typical and help to understand the meaning of suburban homelessness.

\section{Conclusion}

The aim of this research was to obtain an in-depth view of the lived experiences of 15 diverse persons who were homeless in the suburban context. Whether our participants were living on the street, in shelters, or in substandard rooming houses, extreme poverty and the accompanying stress prevented them from eating and sleeping properly, and from regaining secure housing. Lacking income security, many cycled between living on the street and substandard housing. Engulfed in the grotto of poverty they struggled, unable to escape.

As suburban homelessness and poverty remain mostly invisible, public awareness needs to be raised so that effective social policies can be developed to help people to get out of the poverty cycle. While important, something more than empathy is needed for them to escape poverty (Morse, Bottorff, Anderson, O’Brien, \& Solberg, 2006; Zufferey \& Kerr, 2004). Policies that advance equity and support from all levels of community are required. Based in principles of redistributive social justice which focus on outcomes meeting human needs, all citizens deserve adequate housing and to be treated with dignity and respect (Craig, 2002). The rights of all, including the poor, to inhabit the city should be upheld (Klodawsky, 2010). A community-based approach with those who are/have been homeless sitting on the table when policies are developed is essential for success (Minkler \& Wallerstein, 2008).

Raising awareness about homelessness in the suburbs, we hope, will therefore be a first step towards achieving rights-based social justice. We 
need to build a compassionate community in which all citizens have equitable opportunities, enabled by adequate resources, that will prevent them falling into or help them escape from grottoes of poverty. Therefore we believe it is imperative to ensure that the hopes our participants shared with us for a better future can be realized.

\section{References}

Acosta, O., \& Toro, P. A. (2000). Let's ask the homeless people themselves: a needs assessment based on a probability sample of adults. American Journal of Community Psychology, 28(3), 343-361.

Allard, S. W. (2009). Out of reach: Place, poverty and the new American welfare state. New Haven, CT: Yale University Press.

Berube, A., \& Kneebone, E. (2006). Two steps back: City and suburban poverty trends 19992005. Washington, D.C.: The Brookings Institution: Living cities census series. Retrieved from http://www.brookings.edu/research/reports/2006/12/poverty-berube

Boydell, K. M., Goering, P., \& Morrell-Bellai, T. L, (2000). Narratives of identity: Representation of self in people who are homeless. Qualitative Health Research 10, 26-38.

Bryant, T. (2004). Housing and health. In D. Raphael (Ed.), Social determinants of health: Canadian perspectives (pp. 217-232). Toronto: Canadian Scholars' Press.

Cheung, A. M., \& Hwang, S. W. (2004). Risk of death among homeless women: A cohort study and review of the literature. Canadian Medical Association Journal, 170(8), 1243-1249.

City of Toronto. (2009). Street needs assessment: Results and Observations. Retrieved from http:// www.homelesshub.ca/Library/2009-Street-Needs-Assessment-Results-and-Observations-48418. aspx

Clapham, D. (2003). Pathways approaches to homelessness research. Journal of Community and applied Social Psychology, 13(2), 119-127.

Coldwell, C. M., \& Bender, W. S. (2007). The effectiveness of assertive community treatment for homeless people with severe mental illness: a meta-analysis. The American Journal of Psychiatry, 164(3), 393-399.

Connelly, F. S. (2003). Modern art and the grotesque. Cambridge, UK/New York: Cambridge University Press.

Craig, G. (2002). Poverty, social work and social justice. British Journal of Social Work, 32, 669-682.

Daily Bread Foodbank. (2012). Fighting Hunger Retrieved from http://www.dailybread.ca/

Daiski, I. (2008). Perspectives of homeless people on their housing needs and approaches to ensure success. The International Journal of Interdisciplinary Social Sciences, 3(6), 53-61.

Daiski, I. (2007). Perspectives of homeless persons on their health and health needs priorities: Suggestions for health promotion strategies. Journal of Advanced Nursing, 58(3),273-281.

Davis Halifax, N. V., \& Yurichuk, F. (2007). Realistic possibilities of passing interest. Threatening Bodies. Reconstructions: Studies in contemporary culture. Special issue: http:// reconstruction.eserver.org/071/Thestate.shtml

Davis Halifax, N. V., Meeks, J., Yurichuk, F., \& Khandor, E. (2008). A day in the life: Stories and photos of health and homelessness on the streets of Toronto. Progress in Community Health Partnerships: Research, Education, and Action 2(2),_129-136.

Davis Halifax, N. V. (2010). Writing inequity and pursuing hope: Testimonies and witnessings from arts-informed research. In C. McLean \& R. Kelly (Eds.), Creative arts in interdisciplinary practice, inquiries for hope and change (pp. 39-60). Calgary, AB: Detselig/Temeron Books.

Diekelmann, N., Allen, D., \& Tanner, C. (1989). A hermeneutical analysis of the national league for nursing criteria for the appraisal of baccalaureate programs. In N. Diekelmann, D. Allen, \& C. Tanner (Eds.), The national league for nursing criteria for appraisal of baccalaureate programs: A critical hermeneutical analysis (pp. 11-31). New York, NY: National League for Nursing.

Falvo, N. (2008). The housing first model: Immediate access to permanent housing. Canadian 
Housing (Special Edition), 32-38.

Frankish, C. J., Hwang, S. W., \& Quantz, D. (2005). Homelessness and health in Canada: Research lessons and priorities. Canadian Journal of Public Health, 96, Suppl. 2, S23-S29.

Gadamer, H-G. (1990). Truth and method ( $2^{\text {nd }}$ ed.). (J. Weinsheimer \& D. Marshall, Trans.). New York, NY: Crossroad.

Gaetz, S. (2004). Safe streets for whom? Street youth, social exclusion and criminal victimization. Canadian Journal of Criminology and Criminal Justice, 46(4), 423-455.

Gaetz, S. (2008). Homelessness. Retrieved from http://www.homelesshub.ca/Topics/ Homelessness-176.aspx

Gaetz, S., O'Grady, B. \& Buccieri, K. (2010). Surviving crime and violence: Street youth and victimization in Toronto. Toronto: JFCY \& Homeless Hub. Retrieved from http://www. homelesshub.ca

Hilfinger Messias, D. K., DeJong, M. K., \& McLoughlin, K. (2005). Being involved and making a difference: Empowerment and well-being among women living in poverty. Journal of Holistic Nursing, 23(1), 70-88.

Hulchanski, J. D. (2007). The three cities within Toronto: Income polarization among Toronto's neighbourhoods, 1970-2000. Toronto, ON: Cities Centre Press.

Hwang, S. W. (2001). Homelessness and health. Canadian Medical Association Journal, 164(2), 229-233.

Hwang, S. W., Martin, R. E., Tolomiczenko, G. S., \& Hulchanski, J. D. (2003). The relationship between housing conditions and health status of rooming house residents in Toronto. Canadian Journal of Public Health, 94(6), 436.

Jacobs, D. E. (2011). Towards environmental justice and health equity: Environmental disparities in housing. American Journal of Public Health, 101(S1), S115-S122.

Johnson, J. L, Bottorff, J. L, Browne, A. J., Grewal, S., Hilton, B. A., \& Clarke, H. (2004). Othering and being othered in the context of healthcare services. Health Communication, $16(2), 253-271$.

Kearney, R. (1986). Strangers, gods and monsters: Interpreting otherness. Florence, KY, USA: Routledge.

Kirkpatrick, S. I., \& Tarasuk, V. (2009). Food insecurity and participation in community food programs among low-income Toronto families. Canadian Journal of Public Health, 100(2), 135-39.

Klodawsky, F. (2010). Rights to the city: Thinking social justice for chronically homeless women. In D. J. Hulchanski, P. Campsie, S. Chau, S. Hwang, \& E. Paradis (Eds.). Finding home: Policy options for addressing homelessness in Canada. Toronto: Cities Centre, University of Toronto. Retrieved from http://www.homelesshub.ca/Finding Home.

Krieger, N. (2007). Why epidemiologists cannot afford to ignore poverty. Epidemiology, 18, 658-663.

Lafuente, C. R. (2003). Powerlessness and social disaffiliation in homeless men. Journal of Multicultural Nursing and Health, 9(1), 46-54.

Layton, J. (2000). Homelessness: The making and unmaking of a crisis. Toronto, ON: Penguin Books.

Lee, B. A. \& Schreck, C. J. (2005). Danger on the streets. American Behavioural Scientist, 48(8), 1055-1081.

Levy, B. D. \& O’Connell J. J. (2004). Health care for homeless persons. The New England Journal of Medicine, 350(23), 2329-2332.

Massey, D. D. (1996). The age of extremes: Concentrated affluence and poverty in the twentyfirst century. Demography, 33(4), 395-412.

Mikkonen, J. \& Raphael, D. (2010). Social determinants of health: The Canadian facts. Toronto: York University School of Health Policy and Management.

Miller, A. B. \& Keys, C. B. (2001). Understanding dignity in the lives of homeless persons. American Journal of Community Psychology, 29(2), 331-354.

Miller, N. (1982). Heavenly caves: Reflections on the garden grotto. New York, NY: George Braziller.

Minkler, M., \& Wallerstein, N. (2008). Community-based participatory research for health: From process to outcome. San Francisco, CA: Jossey-Bass.

Morse, J. M., Bottorff, J., Anderson, J., O’Brien, B., \& Solberg, S. (2006). Beyond empathy: Expanding expressions of caring. Journal of Advanced Nursing, 53(1), 75-90 
Munhall, P. (2012). Nursing research. A qualitative perspective ( $5^{\text {th }}$ Ed.). Sudbury, MA: Jones \& Bartlett Learning.

National Council of Welfare. (2010). Welfare incomes 2009. Retrieved from http:// www.ncw.gc.ca

Noddings, N. (2002). Caring, social policy and homelessness. Theoretical Medicine, 23(11), 441-454.

O'Connell J. (2004). Dying in the shadows: The challenge of providing health care for homeless people. Canadian Medical Association Journal, 170(8), 1251-1252.

Organization for Economic Co-operation and Development. (1999). The Battle against Exclusion: Social Assistance in Canada and Switzerland. Retrieved from http://www.oecd.org/

Orpana, H. M., Lemyre, L., \& Gravel, R. (2009). Income and psychological distress: The role of the social environment. Health Reports, 20(1). Statistics Canada. Retrieved from http://www. statcan.gc.ca/start-debut-eng.html

Oxford English Dictionary. (2 ${ }^{\text {nd }}$ edition, on-line version). Retrieved from http://www.oed.com. ezproxy.library.yorku.ca/view/Entry/62331

Padgett, D. K. (2007).There's no place like (a) home: Ontological security among persons with serious mental illness in the United States. Social Science and Medicine, 64(9), 1925-1936.

Preston, V., Murdie, R., D’Addario, S., \& Sibanda, P. (2011). Precarious housing and hidden homelessness among refugees, asylum seekers and immigrants in the Toronto Metropolitan Area. Ceris working paper \# 87: The Ontario Metropolis Centre. Retrieved from http:// celarc.ca.ezproxy.library.yorku.ca/cppc/230/230775.pdf

Raphael, D. (Ed.). (2007). Poverty and policy in Canada: Implications for health and quality of life. Toronto: Canadian Scholars Press.

Raphael, D. (2003). Barriers to addressing the societal determinants of health: Public health units and poverty in Canada. Health Promotion International, 18(4), 397-405.

Region of Peel. (2011). Peel Regional Council report: Provincial poverty reduction strategy update, March 14, 2011. Retrieved from http://www.peelregion.ca/council/agendas/pdf/rc20110428/report-hs-a1.pdf

Rokach, A. (2005). Private lives in public places: loneliness of the homeless. Social Indicators Research, 72, 99-114.

Scanlon, C. \& Adlam, J. (2008). Refusal, social exclusion and the cycle of rejection: A cynical analysis. Critical Social Policy, 28(4), 529-549.

Social Planning Council of Peel. (2009). Portraits of Peel 2006 report. Retrieved from http:// ppag.wordpress.com/

Street Health Report. (2007). Toronto: http://www.streethealth.ca/downloads/the-street-healthreport-2007.pdf

Wellesley Institute. (2009). Toronto homeless street count: Lots of heat, but little light (backgrounder). Toronto: Author. Retrieved from http://wellesleyinstitute.com/files/homelesscount2009.pdf

Woolf, S. H. (2007). Future health consequences of the current decline in U.S. household income. JAMA, 298(16), 1931-33.

Zlotnick, C., Robertson, M. J., \& Lahiff, M. (1999). Getting off the streets: Economic resources and residential exits from homelessness. Journal of Community Psychology, 27(2), 209-224.

Zufferey, C., \& Kerr, L. (2004). Identity and everyday experiences of homelessness: Some implications for social work. Australian Social Work, 57(4), 343-353. 